\title{
Effect of fermentation on sensory quality of Liberica coffee beans inoculated with bacteria from saliva Arctictis binturong Raffles, 1821
}

\author{
NENDYO ADHI WIBOWO ${ }^{1,2, \bullet}$, WIBOWO MANGUNWARDOYO ${ }^{1}$, TRI JOKO SANTOSO ${ }^{2}$, YASMAN $^{1}$ \\ ${ }^{1}$ Department of Biology, Faculty of Mathematics and Natural Sciences, Universitas Indonesia. Jl. Prof. Soedjono D. Poesponegoro (Lingkar Kampus \\ Raya), Pondok Cina, Beji, Depok 16424, West Java, Indonesia. Tel./fax.:+62-21-7270163, •email: nendyo.adhi@gmail.com \\ ${ }^{2}$ Indonesian Industrial and Beverages Crops Research Institute. Jl. Raya Pakuwon Km 2, Parungkuda, Sukabumi 43357, West Java, Indonesia
}

Manuscript received: 7 May 2021. Revision accepted: 26 August 2021.

\begin{abstract}
Wibowo NA, Mangunwardoyo W, Santoso TJ, Yasman. 2021. Effect of fermentation on sensory quality of Liberica coffee beans inoculated with bacteria from saliva Arctictis binturong Raffles, 1821. Biodiversitas 22: 3922-3928. Fermentation is one of the post-harvest steps that influence the quality of coffee. This study aims to determine the sensory quality of Liberica coffee beans cv. Liberoid Meranti (LiM) fermented using a consortium of bacteria from saliva Arctictis binturong Raffles, 1821 with varying fermentation periods. Fermentation was performed in a wet process for $0,4,8,12$-hours in triplicate. The parameters observed were caffeine, protein, and fat content. The sensory quality of brewed coffee was conducted refers to the standard Speciality Coffee Association (SCA). The data obtained were processed with Minitab version 16 for Windows and analyzed using ANOVA with a level of $5 \%$ and followed by a post hoc test. The results showed that coffee fermented for $0,4,8,12$ hours has protein content of 15.31-15.67\%; $15.09-16.62 \%$; $12.71-13.07 \%$; 14.64-14.69\%; fat content of $9.48 \%$; $10.20 \%$; $9.96 \%$; $10.21 \%$; and caffeine content of $1.05 \%$; $0.99 \%$; $0.96 \% ; 1.02 \%$, respectively. The length of the fermentation period affects significantly $(\mathrm{p}<0.05)$ the content of protein, fat, and caffeine. The final score of cupping test in coffee fermented for $0,4,8$, and $12 \mathrm{~h}$ were $77.63 ; 78.13 ; 82$; and 80.25, respectively. A fermentation period of 8 and 12 hours improve the flavor score that categorized fermented Liberica coffee as specialty coffee $(8.00-<9.00=$ superior).
\end{abstract}

Keywords: Arctictis binturong, coffee fermentation, Liberica coffee, Liberoid Meranti, specialty coffee

\section{INTRODUCTION}

Liberica coffee (Coffea liberica Bull ex Hiern) is one species of coffee that has gained popularity in recent years. It can adapt well to peatlands and is more tolerant to disease attacks and also known as jackfruit coffee due to its flavor and aroma (Kyaw et al. 2020). There is a limited study conducted on this coffee species as only one percent is cultivated all around the world (Nillian et al. 2020). Liberica coffee is not as bitter as Arabica, however, it has the aroma of jackfruit and sour taste like Arabica (Prasetyo et al. 2019). In the international market, Indonesia has long been known as a producer of high-quality Arabica specialty with a good reputation such as Gayo Coffee, Mandheling Coffee, Lintong Coffee, Java Coffee, Java Preanger Coffee, Toraja Coffee, Kalosi Coffee, Bali-Kintamani Coffee, Flores-Bajawa Coffee, Wamena Coffee, Luwak Coffee. Indonesian robusta specialty coffee including Java-Dampit Robusta, Java Estate Robusta, Bali-Pupuan Robusta, Lampung Robusta, Flores Robusta (Bhatara 2018). In addition, the new type of Liberica coffee found in Indonesia is Liberoid Meranti (Budi 2017).

Coffee is one of the most widely used non-alcoholic beverages, and its consumption is spread globally (Silva 2013). It is the most important commodity on the world market after crude oil (ICO 2019a). Demand for specialty coffee in the world market from year to year is also increasing (Sahat et al. 2018). Indonesia has a geographical advantage as the fourth largest coffee producer in the world (ICO 2019b). According to SCA (2015), specialty coffee is a coffee that has a good taste, with a distinctive taste, aroma and unique based on the specific region of origin, which is usually named according to the region of origin of coffee produced and has a cupping test score above 80 on a scale of 100 . So, it can be said that specialty coffee lies in the high quality of taste. The taste of coffee is strongly influenced by varieties, agroecology (soil type, elevation, climate, fertilization), harvest time, picking method, fermentation process, and storage method (Ahsan et al. 2018).

Coffee quality can be improved with appropriate postharvest processing. The stages of wet-processing coffee beans include sorting, pulping, fermentation, and washing to remove mucus (washing). Coffee fruit will be grouped based on the level of maturity, followed by removing the skin of the fruit. Fermentation can improve the physical quality and taste of coffee beans through changes in the physical and chemical composition of coffee. In wet coffee fermentation, the use of selected starter bacteria can be an alternative to producing coffee with higher quality and distinct aromas, and it is possible to direct the coffee flavor precursors using different strains (Ribeiro et al. 2020). Fermentation time depends on several factors, namely the number of coffee beans, water, temperature, and humidity (Murthy et al. 2011; Simanjuntak 2011). 
Commonly, mucilage causes longer the traditional fermentation coffee process. Several methods have been used to accelerate the fermentation time, among others, by using selected microbes. Ribeiro et al. (2020) selected and used Leuconostoc mesenteroides CCMA 1105 and Lactobacillus plantarum CCMA 1065 as starter cultures in the wet fermentation of pulped coffee. Silva (2013) selected microbes based on their ability to produce pectin lyase and organic compounds, included Bacillus cereus, Bacillus megaterium, Bacillus subtilis, Candida parapsilosis, Pichia carribica, Pichia guilliermondii, and $S$. cerevisiae. Selection based on the profile of aroma compounds, $S$. cerevisiae, $P$. guilliermondii, and $C$. parapsilosis were finally selected as possible future starter cultures for the Brazilian dry fermentation coffee process. The use of pectinase accelerates the pectinolytic process so that the mucilage fermentation time is shorter. Fauzi et al. (2018) produced civet coffee in vitro using yeast inoculum derived from the civet coffee microbiota, it increased water content and total acid concentration, but a decrease in glucose, $\mathrm{pH}$, and caffeine levels. Bacteria from traditional fermented coffee beans have also been widely isolated, such as the genus Enterococcus, Lactobacillus, Leuconostoc, and Weisella (Pereira 2015).

The consortium of bacteria from the saliva of civet Arctictis binturong raffles, 1821 was chosen for coffee fermentation. It is expected to lead to a new perspective on coffee quality other than civet coffee, greater diversification of flavors, and accelerate the removal of the mucilage coffee, and reduce the processing cost. This study aims to determine the content of protein, fat, and caffeine as well as the sensory quality of Liberica coffee beans cv. Liberoid Meranti (LiM) fermented using a consortium of bacteria from saliva Arctictis binturong Raffles, 1821 (Bearcat) with varying fermentation periods.

\section{MATERIALS AND METHODS}

\section{Study site}

The research was conducted at the Integrated Laboratory of Indonesian Industrial and Beverages Crops Research Institute (IIBCRI), Sukabumi, West Java, Indonesia. Liberica cv. LiM coffee fruit was collected at Pakuwon experimental garden belonging to IIBCRI at the coordinates of $6^{\circ} 49^{\prime} 50.82^{\prime \prime} \mathrm{S} 106^{\circ} 44^{\prime} 35.37^{\prime \prime}$ E (Figure 1).

\section{Harvesting of coffee fruit}

Liberica coffee (Coffea liberica Bull ex Hiern) cv. Liberoid Meranti (LiM) coffee fruits were harvested and picked red and selected from fruit defects, then peeled the skin of the fruit using a pulper machine. Ten $\mathrm{kg}$ of peeled coffee fruit was used in every treatment of fermentation and put in the polypropylene bags.

\section{Microbial culture}

The bacterial consortium consisted of Lysinibacillus fusiformis strain Ma-Su CECRI 2, Bacillus cereus strain L77, Bacillus subtilis strain GL2, and Bacillus cereus strain F4a was obtained from the Indonesian Industrial and Beverages Crops Research Institute (IIBCRI). These bacteria consortium was isolated from the saliva of civet Arctictis binturong Raffles, 1821. Bacteria were collectively cultured in $1 \mathrm{~L}$ nutrient broth media (Neogen, NCM0110A) in a 2L volume Erlenmeyer with the addition of $10 \%$ of each bacterial stock. It was incubated for 2- 4 x24 hours at $30^{\circ} \mathrm{C}$ using a shaker at $150 \mathrm{rpm}$ to reach a population density of at least $10^{10} \mathrm{CFU} / \mathrm{mL}$.

\section{Processing of coffee beans}

The wet coffee beans were processed in polypropylene bags. Samples were taken from different batches, and collected at 3 different fermentation time intervals, i.e.,4, 8, and $12 \mathrm{~h}$. All fermentations times were performed in a wet process by adding $1 \mathrm{~L}$ of sterile distilled water in each polypropylene bag, and treatments were carried out in triplicate, and inoculated with $10 \%$ consortium of bacteria. Control treatment, without fermentation $(0 \mathrm{~h})$ was carried out using the traditional honey coffee method which coffee farmers commonly use. The fermentation time was as follows: (i) F0: Nonfermented coffee /without fermentation process, at $0 \mathrm{~h}$, (ii) F1: coffee beans were fermented for 4 hours, (iii) F2: coffee beans were fermented for 8 hours, (iv) F3: coffee beans were fermented for 12 hours.

Coffee beans were dried to approximately $12 \%$ water content and then the skin of coffee horns was peeled with a peeler machine (huller). The dried coffee was used for chemical and sensory analysis. The chemical analyses performed in green beans are caffeine, protein, and fat content, and the sensory test was performed by medium roast to get brewing taste quality.

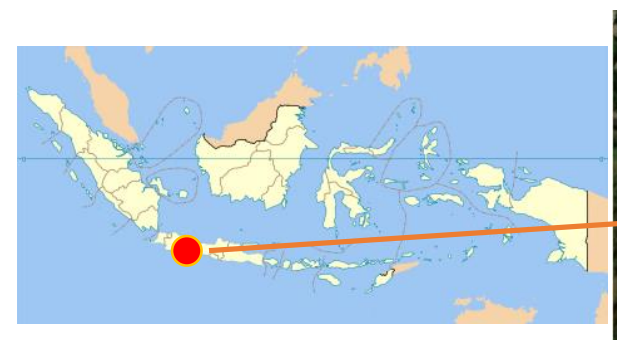

A

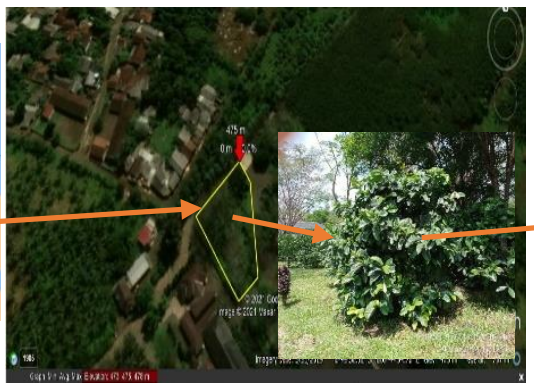

B

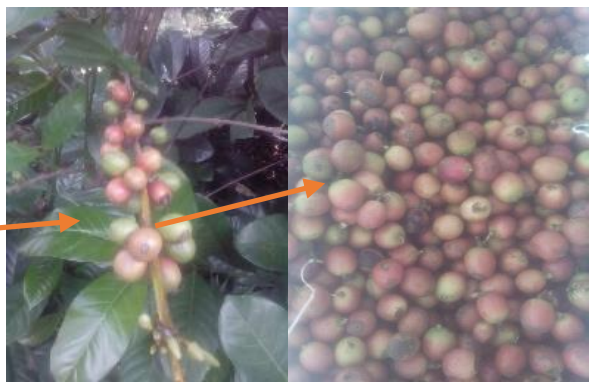

C 
Figure 1. Sampling site of Liberica coffee cv. LiM in Pakuwon experimental garden, West Java, Indonesia. A. Indonesian Map, B. Area sampling Liberica coffee, C. Coffee fruit LiM

\section{Microbial population count}

Microbial analysis were immediately conducted in each fermentation time and performed in serial dilutions to determine microbial population density. About $1 \mathrm{~mL}$ of fermented liquid containing mucilage coffee was added with $9 \mathrm{~mL}$ of sterile $0.89 \% \mathrm{NaCl}$ to obtain $10^{-1}$ dilution. Then, a series of dilutions were carried out up to $10^{-10}$. A $0.1 \mathrm{~mL}$ of sample was taken from the dilution series of $10^{-6}$ to $10^{-10}$, inoculated into nutrient agar media using the pour plate method, and then incubated at $30^{\circ} \mathrm{C}$ for 24 hours. The microbial population was quantified with the total plate count (TPC) method.

\section{Analysis of moisture content}

Analysis of moisture content of fermented coffee was performed by the method of Sudarmaji et al. (2007). Fermented coffee was ground and sieved using a 60-mesh sieve. An empty bottle was dried in an oven at a temperature of $100 \pm 5^{\circ} \mathrm{C}$ for 30 minutes, then cooled in an excavator for 15 minutes, and weighed (a). Two grams of sifted fermented coffee were put in a dry bottle and weighed (b). The weighing bottle containing the sample was put in an oven at a temperature of $100 \pm 5^{\circ} \mathrm{C}$ for 24 hours then cooled in an excavator $( \pm 15$ minutes $)$ and weighed (c). Samples were weighed to a constant weight (difference of $0.0002 \mathrm{~g}$ ). Moisture content is determined using the formula as follows:

$$
\begin{aligned}
& \text { Moisture content }(\%)=(\mathrm{b}-\mathrm{c} / \mathrm{b}-\mathrm{a}) \mathrm{x} 100 \% \text {, } \\
& \text { Note: } \\
& \text { a: weight of the empty bottle } \\
& \text { b: weight of bottle + sample before drying in the oven } \\
& \text { c: weight of bottle + sample after drying in the oven }
\end{aligned}
$$

\section{Spectrophotometric analysis of caffeine}

Analysis of caffeine of fermented coffee was performed by UV/Vis spectrophotometry analysis according to Aprilia et al. (2018). One g of coffee powder was put into a beaker glass, added $150 \mathrm{~mL}$ of sterile water, then stirred and heated. The hot coffee solution was filtered through the mouthpiece with filter paper in an Erlenmeyer, then 1,5 g of calcium carbonate $\left(\mathrm{CaCO}_{3}\right)$ was added. The coffee solution was inserted into a separating funnel, extracted with $25 \mathrm{ml}$ of chloroform, and extracted 4 times. The chloroform layer was taken, then centrifugated to precipitate calcium carbonate. The filtrate was concentrated using a rotary evaporator. The solvent-free caffeine extract was put into a $100 \mathrm{~mL}$ mustard flask, and diluted until the boundary mark line and homogenized. The solution is diluted again as much as 4 times. The same treatment is done for each sample. The determination of wavelengths is done by observing the absorption of standard solutions in the wavelength range of $200-700 \mathrm{~nm}$ using a UV-Vis spectrophotometer. Based on the standard curve from the standard solution, it was obtained that the maximum wavelength was $273 \mathrm{~nm}$. The caffeine content of each sample was measured at a wavelength of $273 \mathrm{~nm}$.

\section{Analysis of protein degradation}

Analysis of protein degradation is carried out by the nitrogen formol method (AOAC 2005). As much as $2 \mathrm{~g}$ of fermented coffee beans were ground and sieved with a size of 60 mesh. The coffee powder was dissolved in $20 \mathrm{~mL}$ sterile water and homogenized. The solution is filtered using Whatman filter paper \# 41. The filtrate was put in a $100 \mathrm{~mL}$ measuring flask. The precipitate is re-extracted using sterile water and filtered using Whatman filter paper \# 41. The filtrate is put in a mustard flask and diluted to $100 \mathrm{~mL}$. Ten $\mathrm{ml}$ was inserted into the Erlenmeyer and added with $20 \mathrm{~mL}$ sterile water and $1 \mathrm{~mL}$ of $1 \%$ phenolphthalein indicator. The solution was mixed gently for 2 minutes. The sample solution is then titrated using $\mathrm{NaOH} 0.01 \mathrm{~N}$ until it turns pink followed by adding $2 \mathrm{~mL}$ formaldehyde $37 \%$ and re-titrated with a solution of $\mathrm{NaOH}$ $0.01 \mathrm{~N}$ until the color of the solution becomes red. The number of $\mathrm{NaOH}$ used for titration is recorded. Blank solution ( $20 \mathrm{~mL}$ of sterile water) is added with $1 \mathrm{~mL}$ of $1 \%$ phenolphthalein indicator and was titrated using $\mathrm{NaOH}$ $0.01 \mathrm{~N}$ until it turns pink followed by adding $2 \mathrm{~mL}$ formaldehyde $37 \%$ and re-titrated with a solution of $\mathrm{NaOH}$ $0.01 \mathrm{~N}$ until the color of the solution becomes red. The number of $\mathrm{NaOH}$ used for titration is recorded.

\section{Analysis of fat content}

The fat content of fermented coffee beans was determined by the Soxhlet extraction method (AOAC 2005). As many $\pm 5 \mathrm{~g}$ of sample (W0) place in the thimble and put in that has weighed its permanent weight (W1) and connected to the soxhlet tube. The flask was placed into the soxhlet extractor chamber and added with n-hexane as a solvent. The solution was refluxed for \pm 3 hours. The solvent that contained fat in the flask was distilled until all the solvent was evaporated (rpm 50, temperature $69^{\circ} \mathrm{C}$ ). The flask was dried in an oven at a temperature of $105^{\circ} \mathrm{C}$ and then place in the desiccator until it reached a constant weight (W2). Fat content is determined using the formula as follows:

$$
\begin{aligned}
& \quad \text { Fat }(\%)=(\mathrm{W} 2-\mathrm{W} 1) / \mathrm{W} 0 \times 100 \% \text {, } \\
& \text { Note: } \\
& \text { W0: weight of samples }(\mathrm{g}), \\
& \text { W1: weight empty fat tube }(\mathrm{g}), \\
& \text { W2: weight tube with fat }(\mathrm{g}) \text {. }
\end{aligned}
$$

\section{Sensory evaluation of coffee}

Sensory evaluation (cupping test) was conducted on the powder of roasted medium green bean coffee refers to the standard Speciality Coffee Association / SCA using 3 expert panelists / trained (SCA 2015). The observed parameters refer to Robusta protocol, i.e., fragrance, flavor (tongue), aftertaste (taste left mouthed), salt/acid, bitter/sweet, mouthfeel/body, uniform cup, balance (an aspect of flavor balance), clean cup (general taste impression), overall (an aspect of overall taste), taint. The scale of taste parameter was: $6.00-<7.00=$ good; 7.00 $<8.00=$ very good; $8.00-<9.00=$ superior; $9.00-<10.00=$ 
outstanding; $10=$ excellent. If the total value of the quality score of brewed coffee was $\geq 80$ on a scale of 100 based on the cupping test, it can be categorized as specialty coffee (SCA 2015).

\section{Data analysis}

The data obtained from each parameter based on the length of fermentation time were processed using the statistical application of Minitab version 16 for Windows and analyzed using ANOVA with a level of 5\%. If there is a significant difference from the F-test result $(\mathrm{p}<0.05)$, then proceed with the post hoc test to determine the significant difference between each parameter. The data was presented in tabular form.

\section{RESULTS AND DISCUSSION}

\section{Fermentative process}

The fermentation process of coffee beans was carried out to improve the quality of Liberica coffee beans cv. LiM. During the fermentation process, a microbial consortium grows which indicates the fermentation process is in progress. Growth differences were caused by physiological diversity and different responses to physical and environmental conditions. Total bacteria at the $0,4,8$, 12 hours of the fermentation process, and $\mathrm{pH}$ was presented in Figure 2.

The results showed that the bacterial consortium of Bacillus cereus strain L77, Bacillus subtilis strain GL2, Bacillus cereus strain F4a, and Lysinibacillus fusiformis strain Ma-Su CECRI 2 grew optimally at 8 hours of fermentation with a $\mathrm{pH}$ of 5.7. The $\mathrm{pH}$ value of media was decreased along with fermentation time and population growth, however, the $\mathrm{pH}$ value slightly increased at 4 to 8 hours of fermentation time but no significant and possibility of reduced organic acid production. According to Kanza et al. (2020) reduced alpha-amylase activity and ion $\mathrm{Ca}^{2+}$ on the hydrolysis of starch pulp in fermented Liberica coffee resulted in reduced acid production. Microbial profiles in coffee can differ depending on geographical origin, processing method (dry or wet), coffee species, soil topography, and edaphic factors (Pereira et al. 2020). The decrease in $\mathrm{pH}$ value during the fermentation process was caused by organic acids produced during fermentation due to microbial metabolism. An essential medium is important to maintain the viability of starter culture in fermented coffee fermentation (Ribeiro et al. 2020). A study by Havare et al. (2019) showed that a starter culture containing the consortia of Saccharomyces cerevisiae, Lactobacillus plantarum, and Bacillus sphaericus $(1: 1: 1)$ at $10 \%$ inoculum concentration was found significant in demucilizatin of Arabica coffee beans. Moreover, the study showed that the fermentation was completed within 6-8 h while natural fermentation was completed within $16 \mathrm{~h}$ and the $\mathrm{pH}$ decreased from 5.5-6.0 to 3.5-4.0. A previous study by Lee et al. (2015) showed that bacteria in semi-wet fermentation of coffee beans include Acetobacter, Bacillus brevis, Bacillus lichonifermis, Bacillus cereus, Enterobacteriaceae,
Lactobacillus brevis, Leifsonia aquatica, Leuconostoc mesenteroides, Pseudomonas, Streptococcus faecium, Vibrio, but only Bacillus cereus, Bacillus lichonifermis, Bacillus brevis, and Enterobacteriaceae which have an important role in improving the quality of coffee aroma. The fermentation process on low-quality coffee could improve its quality (Afriliana et al. 2018). Fermentation improves the physical quality and taste of coffee beans through physical changes and chemical composition. Fermentation time depends on several factors, namely the number of coffee beans, water, temperature, and humidity (Murthy et al. 2011; Simanjuntak 2011). The formulation and optimization of the starter consortia had an impact on the coffee flavor profiles. The starter culture-mediated fermentation will undergo demucilage with the action of microbiota uniformly thereby improving the physical, chemical, and sensory profile of the coffee (Havare et al. 2019).

\section{Chemical composition of Liberica green coffee bean}

The results of the analysis of fermented green coffee beans including protein, fat, and caffeine content were presented in Table 2. According to Pereira et al. (2020), the sensory and chemical composition of coffee was dominantly affected by metabolites generated by microorganisms that act spontaneously or are induced during fermentation (Pereira et al. 2020). The chemical composition of green coffee bean coffee greatly affects the taste of brewed coffee. Hydrolysis of protein into amino acids affects significantly coffee aroma because amino acids are important aroma precursors during roasting. Protein hydrolysis reduces the bitterness and acidity in coffee drinks. Protein breakdown causes a decrease in the caffeine content of coffee and an increase in free amino acids (Marcone 2019). Fat content is a potential differentiator of specialty coffee quality, indicating better sensory qualities and may be related to less intense acidity, fragrance, body, and flavor (Figueiredo et al. 2015). Protein content in coffee fermented for $0,4,8,12$ hours in this study ranged from 15.31-15.67\%; $15,09-16,62 \%$; $12,71-$ $13,07 \% ; 14,64-14,69 \%$, respectively. Fat content in coffee fermented for $0,4,8,12$ hours in this study ranged from $9.48 \% ; 10,20 \% ; 9,96 \% ; 10,21 \%$, respectively. While caffeine content in coffee fermented for $0,4,8,12$ hours in this study ranged from $1.05 \% ; 0,99 \% ; 0,96 \% ; 1,02 \%$, respectively. The length of fermentation time significantly affects the protein, fat, and caffeine content of Liberica coffee (Table 2).

Table 2. The protein, fat, and caffeine content in Liberica coffee with varying lengths of fermentation time

\begin{tabular}{llll}
\hline Treatment & Protein & Fat & Caffeine \\
\hline F 0 & $15,4650 \mathrm{a}$ & $9,48000 \mathrm{a}$ & $1,0500000 \mathrm{a}$ \\
F 1 & $15,8550 \mathrm{a}$ & $10,19500 \mathrm{~b}$ & $0,9900000 \mathrm{~b}$ \\
F 2 & $12,8900 \mathrm{~b}$ & $9,96000 \mathrm{c}$ & $0,9600000 \mathrm{c}$ \\
F 3 & $14,6650 \mathrm{ab}$ & $10,21000 \mathrm{~d}$ & $1,0200000 \mathrm{~d}$ \\
\hline
\end{tabular}

Note: F0: no-fermentation; F1: fermented for $4 \mathrm{~h}$; F2: fermented for $8 \mathrm{~h}$, ; F3: fermented for $12 \mathrm{~h}$. *The numbers followed by the same letter showed no significant difference at a confidence level of $95 \%$. 


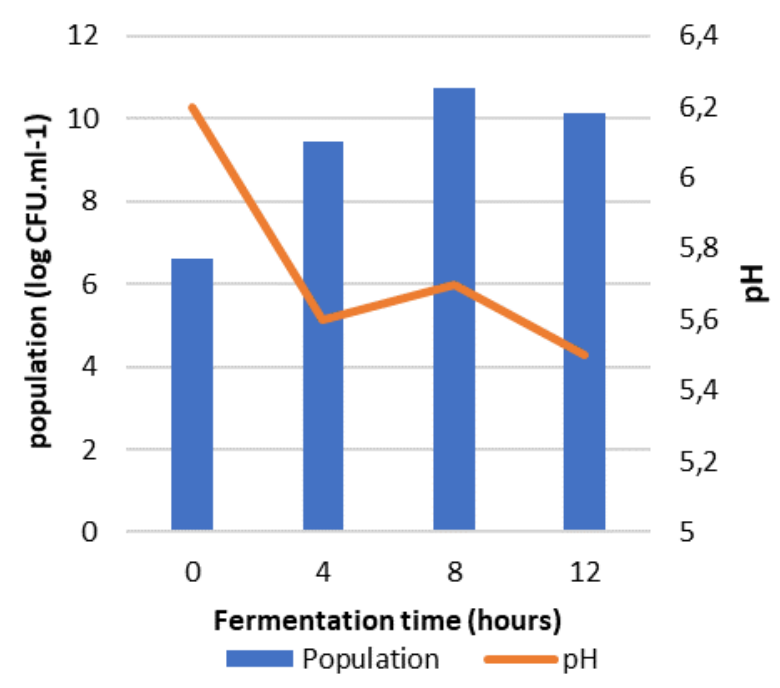

Figure 2. Total population of bacterial consortium related to fermentation time (hours)

The lowest protein content was obtained in coffee fermented for $8 \mathrm{~h}$ (F2) (8 hours), while protein content in non-fermented coffee (F0), and coffee fermented for $4 \mathrm{~h}$ (F1) and $12 \mathrm{~h} \mathrm{(F3)} \mathrm{were} \mathrm{not} \mathrm{significantly} \mathrm{different}$ ( $>0.05)$. The lower protein levels result in lower levels of coffee bitterness as proteins serve as the precursors of bitter compounds during coffee roasting (Marcone 2019; and Janzen 2010). In the fermentation process, proteins break down into compounds such as peptides and amino acids (Selmar et al. 2014; Lin 2010). The starter cultures and the type of processing during the fermentation and drying processes influence the coffee protein profile (Bressani et al. 2020).

Another chemical compound that influences the coffee flavor is fat content. In coffee, The fat in coffee is found on the outside of the beans in the form of a waxy layer that serves as bean protection and forms an oil layer when roasted. The highest fat content $(10.21 \%)$ was obtained in coffee fermented for 12 hours. A previous study by Mahendradatta et al. (2011) showed that the quality of civet coffee flavor was better due to low protein content and high-fat content than ordinary coffee. Low protein content can reduce bitterness, while high-fat content can increase the body (Marcone 2019). Oil in coffee that is produced during roasting contains triglycerides with linoleic acids content of $40-50 \%$ and palmitic acid of 30-35\%. Excessive fermentation causes the coffee flavor to be too light and poorly tasted (Murthy et al. 2011).

Analysis of caffeine was carried out to determine the rate of decreasing caffeine due to the fermentation process in Liberica coffee beans. Caffeine is an alkaloid that is naturally found in more than 60 species of plants, especially coffee. The results of the ANOVA analysis showed the length of fermentation time affected caffeine levels of Liberica coffee $(p<0.05)$. The results showed that the length of fermentation time decreases caffeine content significantly $(\mathrm{p}<0.05)$, except $12 \mathrm{~h}$ fermentation time. The

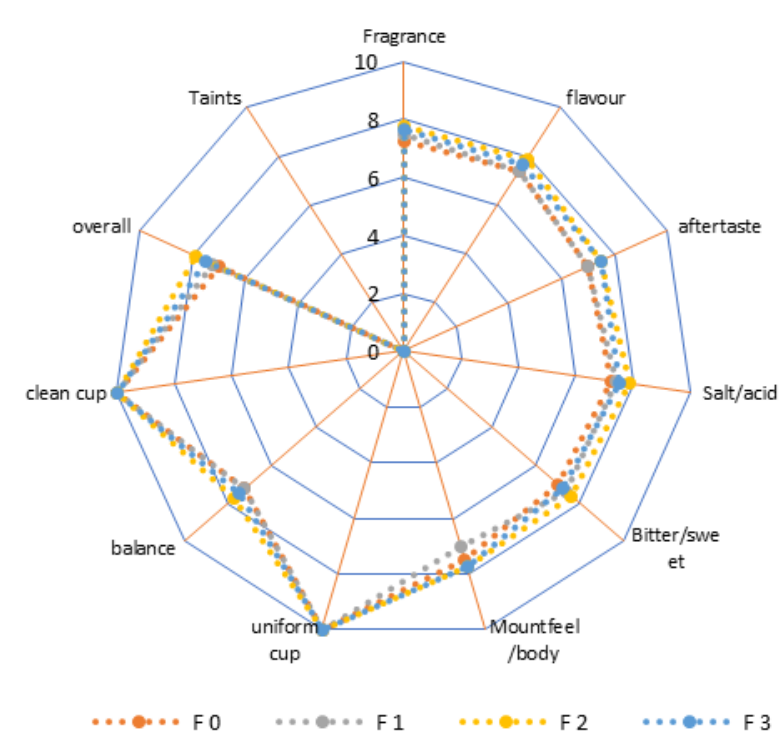

Figure 3. Cup taste profile of Liberica coffee beans. Note: F0: nofermentation; F1: fermented for $4 \mathrm{~h}$; F2: fermented for $8 \mathrm{~h}$, ; F3: fermented for $12 \mathrm{~h}$

lowest caffeine content was found in coffee fermented for 8 hours. Farida (2013) stated that the longer the fermentation process, the lower the caffeine content in coffee beans. It is due to the presence of proteolytic bacteria that produce fairly high proteolytic enzymes. Protein breakdown causes a decrease in caffeine levels in coffee and an increase of free amino acids (Marcone 2004). The best fermentation treatment is the one that influences protein, fat, and caffeine content and leads to better sensory quality.

\section{Sensory quality of liberica coffee}

Quality is the most important aspect of coffee marketing. The sensory and visual quality characteristics of coffee are the accumulation of various parameters during processing (Huch and Franz 2015). Liberica coffee fermented for $0,4,8$, and 12 hours have different profiling in cup taste profile (Figure 3). The final score of sensory quality on the medium roast in samples fermented for 8 and 12 hours was greater than 80 on a scale of 100 . According to SCA (2015), a cupping test score $>80$ on a scale of 100 can be categorized as specialty coffee that has a good taste, aroma, and uniqueness. The highest score was found in coffee fermented for 8 and 12 hours. Based on the flavor score, Liberica cv. LiM coffee could be categorized as a reputable coffee with excellent potential to develop more widely in the market (Table 3 ). There are significant differences $(\mathrm{P}<0.05)$ on all sensory attributes.

Based on the results, fragrance and flavor characteristics in all treatments have a score range of 7,257,88 indicating that Liberica coffee is categorized as very good coffee $(7,00-7,75)$. The treatment of $8 \mathrm{~h}$ fermentation time has the highest fragrance score of 7,75. The fragrance is the aspect that includes the smell of coffee powder, while the smell is an odor when the coffee is brewed with hot water. The addition of inoculum influences the aroma of coffee. Glucose is used as a source of energy to produce metabolites in the form of organic acids that serve as a 
precursor of flavor in coffee (Avallone et al. 2001). In addition, the roasting temperature also affects the formation of the fragrance or aroma of coffee beans. Standard roasting (medium) results in a chocolate aroma, but higher temperature burns the compounds aside from sugar browning (Yusianto and Widyotomo 2013).

The flavor is the fusion of aroma, acidity, and aftertaste. The quality of the taste in coffee is influenced by the combination of taste and aroma when the coffee is drunk. Fermented Liberica coffee beans for $8 \mathrm{~h}$ have the highest score of flavor that is equal to 7,88. The aftertaste characteristic is the tastes and aromas left in the mouth after swallowing. The low value of aftertaste means that coffee has a short aftertaste which can be caused by too strong or predominant acidity or most of the lingering aftertaste of coffee is due to heavy and low water-soluble bitter melanoidins (Münchow et al. 2020).

Good acidity in coffee describes as a delicious, sweet, and fresh like fresh fruit which is immediately felt when coffee is swallowed. Sweetness characteristic is interpreted with a sweet taste in coffee. The 8-h fermentation had the highest sweetness score of 7.63. The breakdown of carbohydrates causes the emergence of sweetness characteristics in coffee beans into glucose during the fermentation process that affects the sweet taste (Redgwell 2006). A high sweetness value is associated with a lower bitterness character due to protein breakdown into amino acids. The lower the protein content, the less bitter the coffee (Marcone 2019). The score of the body varied according to the fermentation time. The samples with an intense body usually receive a high score in terms of quality due to more solids dissolved in the beverage.

The mouthfeel/body is based on the taste when the fluid enters the mouth especially between the tongue and the palate. The uniform cup is the uniformity of the aroma in each bowl, while the clean cup shows no negative value from the beginning of the flavor until the aftertaste. The organoleptic characteristics of coffee fermented with consortia starters have better quality than naturally fermented coffee (Havare et al. 2019).

Table 3. Results of sensory evaluation of Liberica coffee with varying length of fermentation time

\begin{tabular}{|c|c|c|c|c|}
\hline Attribute & F0 & F1 & F2 & F3 \\
\hline Fragrance & 7.25 & 7.5 & 7.75 & 7.63 \\
\hline Flavor & 7.38 & 7.38 & 7.88 & 7.63 \\
\hline Aftertaste & 7 & 7 & 7.5 & 7.5 \\
\hline Salt/acid & 7.25 & 7.38 & 7.88 & 7.5 \\
\hline Bitter/sweet & 7 & 7.38 & 7.63 & 7.25 \\
\hline Mouthfeel/body & 7.5 & 7 & 7.75 & 7.75 \\
\hline Uniform cup & 10 & 10 & 10 & 10 \\
\hline Balance & 7.25 & 7.25 & 7.75 & 7.5 \\
\hline Clean cup & 10 & 10 & 10 & 10 \\
\hline Overall & 7 & 7.25 & 7.88 & 7.5 \\
\hline Taints & 0 & 0 & 0 & 0 \\
\hline Final Score & 77.63 & 78.13 & 82 & 80.25 \\
\hline
\end{tabular}

Note : F0: no-fermentation; F1: fermented for 4 h; ; F2: fermented for 8 h, ; F3: fermented for $12 \mathrm{~h}$
To conclude, Liberica coffee cv. Liberoid Meranti (LiM) fermented using a consortium Bacillus cereus strain L77, Bacillus subtilis strain GL2, Bacillus cereus strain F4a, and Lysinibacillus fusiformis strain Ma-Su CECRI 2 promotes unique interactions in changes in sensory, chemical, and microbiological profiles. $\mathrm{pH}$ values tended to decrease due to acid production by bacterial population growth. The content of protein, fat, and caffeine in Liberica fermented green bean coffee greatly affects the taste in brewed coffee. Fermentation time of 8 and 12 hours improves the taste so that Liberica fermented coffee is categorized as Liberica specialty coffee $(8.00-<9.00=$ superior). The flavor score of coffee Liberica cv. LiM is categorized as a reputable coffee that has excellent potential to be developed in the wider market.

\section{ACKNOWLEDGEMENTS}

The authors would like to thank Universitas Indonesia for funding this research through PUTI Grant with contract number NKB-615/UN2.RST/HKP.05.00/2020 to Prof. Wibowo Mangunwardoyo. We also thank Dr. Fadjry Djufry from Indonesian Industrial and Beverages Crops Research Institute (IIBCRI), Sukabumi, Indonesia for supporting this work.

\section{REFERENCES}

Afriliana A, Harada H, Khotijah PQ, Giyarto J. 2018. Fermented technology of robusta coffee beans (Canephora coffee) with kefir milk to produce specialty coffee. Adv Eng Res, 172, 302-309.

Ahsan H, Syed AH, Hafiz ARS. 2018. "Coffee Bean-Related" agroecological factors affecting the coffee. In: Mérillon JM, Ramawat KG (eds) Springer Nature Switzerland, Co-Evolution of Secondary Metabolites, Reference Series in Phytochemistry. DOI : 10.1007/9783-319-76887-8_21-1

AOAC. 2005. Official Methods of Analysis of the Association of Official Analytical Chemists. Published by the Association of Official Analytical Chemist, Maryland.

Aprilia FA, Ayuliansari Y, Putri T, Azis YM, Camelina DW, Putra RM. 2018. Analisis kandungan kafein dalam kopi tradisional gayo dan kopi lombok menggunakan HPLC dan spektrofotometri UV-Vis. Biotika 16 (2): 38-39. [Indonesia]

Avallone S, Guiraud JP, Guyot B, Olguin E, Brillouet JM. 2000. Polysaccharide constituents of coffee-bean Mucilage. J Food Sci 65 (8): 1308-1311. DOI: 10.1111/j.1365-2621.2000.tb10602.x.

Bhatara BN. 2018. Spesialty Kopi Indonesia, Directorate General for National Eksport Development, Ministry of Trade Republic Indonesia. Warta Ekspor Ditjen PEN/MJL/13/II/2018.

Bressani AP, Martinez SJ, Vilela LD, Dias DR, Schwan RF. 2020. Coffee protein profiles during fermentation using different yeast inoculation methods. Pesquisa Agropecuária Brasileira 55. DOI: 10.1590/S16783921.pab2020.v55.01159.

Budi M. 2017. Performance of the selected main tree of liberoid coffee in the peatland of Kepulauan Meranti, Riau. J Wetlands Environ Manag 5 (1): 32-36. DOI: $10.20527 /$ jwem. v5i1.126

Farida A, Ristanti E, Kumoro AC. 2013. Penurunan Kadar kafein dan asam Total pada biji kopi robusta menggunakan teknologi fermentasi anaerob fakultatif dengan mikroba Nopkor MZ-15. Jurnal Teknologi Kimia dan Industri 2 (2): 70-75. [Indonesia]

Fauzi M, Choiron M, Puji AY. 2018. Chemical Characteristics of Artificial Robusta Civet Coffee Fermented by Luwak Yeast and AAmylase. J Postharvest Agric Res 14 (3): 144 . DOI: 10.21082/jpasca.v14n3.2017.144-153 [Indonesia]

Figueiredo LP, Borém FM, Ribeiro FC, Giomo G S, Taveira JH, Marcelo RM. 2015. Fatty acid profiles and parameters of quality of specialty 
coffees produced in different Brazilian regions. Afr J Agric Res 10 (35): 3484-3493. DOI: 10.5897/AJAR2015.9697

Havare D, Basavaraj K, Murthy PS. 2019. Coffee starter microbiome and in-silico approach to improve Arabica coffee. LWT 114: 108382.

Huch M, Franz CM. 2015. Coffee: fermentation and microbiota. In Advances in fermented foods and beverages. Woodhead Publishing. DOI: $10.1016 / \mathrm{B} 978-1-78242-015-6.00021-9 . \mathrm{p}:$ 501-511.

ICO. 2019a. Total production by all exporting countries, International Coffee Organization

ICO. $2019 \mathrm{~b}$. Total production by all exporting countries In thousand $60 \mathrm{~kg}$ bags. International Coffee Organization.

Janzen SO. 2010. Chemistry of coffee. In: Mender L, Liu HW (eds) Comprehensive Natural Products II, Chemistry and Biology. Elsevier Ltd., Kidlington, UK. DOI: 10.1016/B978-008045382-8.00708-5

Kanza NR, Sudarti, Maryani. 2020. Effect of Exposure to Extremely Low Frequency (Elf) Magnetic Field (Elf) on pH and Electricity on The Wet Fermentation Process of Liberica Coffee (Coffea liberica) With Additional -Amylase. ORBITA. J Stud Results Innov Appl Phys Educ 6 (2): 315-321. DOI: 10.31764/orbita.v6i2.3294 [Indonesia]

Kyaw EiM, Budiastra IW, Sutrisno, Samsudin, Mala DM. 2020 Prediction of caffeine content in liberica coffee green bean by nir spectroscopy using Kubelka-Munk model. Jurnal Tanaman Industri dan Penyegar 7 (3): 119-126. DOI:10.21082/jtidp. v7n3.2020.p119126 [Indonesian]

Lee LW, Cheong MW, Curran P, Yu B, Liu SQ. 2015. Coffee fermentation and flavor-An intricate and delicate relationship. Food Chem 185: 182-191. DOI : 10.1016/j.foodchem.2015.03.124.

Lin CC. 2010. Approach of improving coffee industry in Taiwan-promote quality of coffee bean by fermentation. J Int Manag Stud 5 (1): 154 159.

Mahendradatta M, Zainal I, Tawali AB. 2011. Comparison of chemical characteristics and sensory value between luwak coffee and original coffee from arabica (Coffea arabica L.) and robusta (Coffea canephora L.) varieties. Makassar: Department of Agricultural Technology, Faculty of Agriculture, Hasanuddin University.

Marcone MF. 2004. Composition and properties of Indonesian palm civet coffee (Kopi Luwak) and Ethiopian civet coffee. Food Res Int 37 (9): 901-912. DOI: 10.1016/j.foodres.2004.05.008.

Marcone MF, Alrifai O. 2019. Origins and Compositional Analysis of Novel Foods: Kopi Luwak Coffee and Bird's Nest Soup. DOI 10.1016/B978-0-444-64046-8.00251-2

Münchow M, Alstrup J, Steen I, Giacalone D. 2020. Roasting conditions and coffee flavor: A multi-study empirical investigation. Beverages 6 (2): 29. DOI: 10.3390/beverages 6020029
Murthy PS, Naidu MM. 2011. Improvement of robusta coffee fermentation with microbial enzymes. Eur J Appl Sci 3 (4): 130-139.

Nillian E, Nurhuda S, Ismail, Muhamad EB, Buyong NL, Ngui SN, Dayang SAA, Ahmad A. 2020. The feasibility study of physicochemical properties of sarawak Liberica sp. Coffee Pulp. Pertanika J Trop Agric Sci 43 (4): 477 - 490. DOI: 10.47836/pjtas.43.4.05

Pereira LL, Guarçoni RC, Pinheiro PF, Osório VM, Pinheiro CA, Moreira TR. 2020. New propositions about coffee wet processing: Chemical and sensory perspectives. Food Chem 310: 125943. DOI: 10.1016/j. foodchem.2019.125943

Prasetyo P, Hidayat R, Nyoto, Purnomo H. 2019. Liberica Coffee Cultivation in Peatlands. Center for International Forestry Research (CIFOR) 4, Bogor. [Indonesia]

Pereira GVDM. 2015. The potential use of yeast starter cultures to improve the fermentation and quality of coffee during wet processing: selection, implementation and sensorial effects.

Redgwell R, Fischer M. 2006. Coffee carbohydrates. Braz J Plant Physiol 18 (1): 165-174. DOI: S1677-04202006000100012

Ribeiro LS, Miguel MGCP, Martinez. SJ, Bressani APP, Evangelista SR, Batista CFS, Schwan RF. 2020. The use of mesophilic and lactic acid bacteria strains as starter cultures for improvement of coffee beans wet fermentation. World J Microbiol Biotechnol 36: 186. DOI: 10.1007/s11274-020-02963-7

Sahat SF, Nuryartono N, Hutagaol MP. 2018. Analysis of coffee export development in Indonesia. J Econ Dev Policy 5 (1): 63-89. DOI: 10.29244/jekp.5.1.63-89 [Indonesia]

SCA. 2015. Protocols Cupping Specialty Coffee, Specialty Coffee Association of America.

Selmar DI, Kleinwächter MA, Bytof GE. 2014. Metabolic responses of coffee beans during processing and their impact on coffee flavor. Cocoa Coffee Fermentations 431-476.

Silva CF. 2013. Evaluation of a potential starter culture for enhancing quality of coffee fermentation. World J Microbiol Biotechnol 29 (2): 235-247. DOI: $10.1007 / \mathrm{s} 11274-012-1175-2$

Simanjuntak R. 2011. Articles on The Science of Food Ingredients Fresheners. UNDIP, Semarang. [Indonesian]

Sudarmaji S, Haryono B, Suhardi. 2007. Analysis of Food and Agricultural Materials. Liberty, Yogyakarta. [Indonesian]

Yusianto Y, Widyotomo S. 2013. Quality and flavor profiles of arabica coffee processed by some fermentation treatments: Temperature, containers, and fermentation agents addition. Pelita Perkebunan 29 (3): 155894 . DOI: $10.22302 /$ iccri.jur.pelitaperkebunan.v29i3.14 [Indonesian] 